\title{
帯関数を用いたパネルの比較判別能力の分析
}

\author{
鳥 海 不二夫*・高 山 潤 也* \\ 大 山真 司*.小林涁*
}

\section{Analysis of Panel's Inspection Abilities Using Band Function Model}

\author{
Fujio TORIUmi* ${ }^{*}$, Jun-ya Takayama*, \\ Shinji OHYAMA* and Akira KoBAYASHI
}

\begin{abstract}
Sensory evaluation can be broadly classified to analytic methods and a preference surveys. In the analytic methods, especially, since the panels are used as measuring instruments, sufficient inspection abilities are required to panels. The inspection abilities of a panel depend on various external factors or panel's attributes such as sex, age, etc. Then it is important to consider the attributes which have influence to the panel's inspection abilities. After we analyzed them, it is able to select appropriated panel to examination. The characteristics of panel's appear as the shapes of judgment characteristic functions. Therefore, by analyzing the shapes of judgment characteristic functions of the panels, it is able to evaluate the inspection ability of the panels. In this study, we focus on the difference of judgment characteristic function among panels. Then, we propose the method to evaluate obtaining panel's inspection abilities. Two kinds of evaluation indexes, "the judgment dispersion" and 'the resolution" are defined from panel's characteristic functions of judgment. Simulation shows the validities of these evaluation indexes. Consequently, it may be clear that it is able to evaluate the inspection abilities of panels by the proposed evaluation indexes. Then, the evaluation indexes are applied to two actual experiments. From the first experiment, comparison of chroma saturation, we changed information which given to each panels, to analyze the difference of inspection abilities of panels. This experiment shows that the selection of suited information for experiment becomes easier by using proposed evaluation indexes. In the second experiment, the comparison of likeness of pearl, we analyzed the influences of sex and given knowledge of panel. This experiment shows the possibility to classify panels that have suitable inspection abilities, easily by using proposed evaluation indexes.
\end{abstract}

Key Words: paired comparison, sensory evaluation, panel, inspection ability

\section{1.はじめに}

人間の感覚による計測, すなわち官能検査に関連する尺度 付けの手法の一つに一対比較法がある。一般に，この一対比 較法は比較的曖昧な量の尺度づけを行なう場合に利用される が, 一対比較を行なうパネルは, 尺度付けすべき対象 (量) としての刺激に関する充分な知識をもたない場合が多く,さ らに, 対象とする刺激に関する説明が不充分なために, 検査 者の意図とは異なるイメージの刺激についてパネルが比較判 断することもある。このような場合, パネルの判断結果に含 まれる曖昧さはより増大し, 得られたデー夕をそのまま用い ると, 求めたい刺激についての尺度づけから離れた結果が得

\footnotetext{
* 東京工業大学大学院理工学研究科. 東京都目黒区大岡川 2-12-1

* Graduate School of Science and Engineering, Tokyo

Institute of Technology, Meguro-ku, Tokyo

(Received December 19, 2002)

(Revised April 24, 2003)
}

られてしまう可能性がある。この意味で，パネルが適切な検 査能力を持っているかどうかを確認することは重要である.

一方, パネルの検査への適性は, さまざまな外的要因やパ ネルの持つ属性 (性別や年齢など) によって変化する。した がって, パネルの持つ属性や環境などが与える検査への影響 を分析する必要もある．このとき，パネルを属性や実験環境 によっていくつかのグループに分け，それぞれのグループご との検査能力を調べることができれば，検査に適した環境 およびパネルの属性を明らかにすることが可能となる。つ まり，より精密な尺度付けを行なうためには官能検査を行な う各パネルの持つ検査能力を適確に把握することが求めら れる。

さて，一対比較法においては一意性と一致性の観点からパ ネルの検査への適性が評価されることが多い ${ }^{1)}$.このうち一 意性は, 主にパネル個人の検査能力を調べるのに用いられ る.また, 一致性はパネル相互間の判断に関する一致の度合 いを調べるのに用いられる。しかし，これら二つの手法は， 
多く一対比較デー夕の直接的分析に基づいてパネルの検査 能力を測定するという手法をとっているため, 検査への適性 の有無のみを判断する方法であり, パネルの検査能力の程度 を数量的に評価することはできない.

これに対し, 本研究ではパネルがどの程度の刺激差に対し てどのような比較判断を示すか, すなわち, どのような判断 特性を持っているかを, 帯関数モデル型一対比較法 (BMPC 法)に基づいて明らかにしつつパネルの検査能力の測定を行 なう. $\mathrm{BMPC}$ 法 ${ }^{2), 3)}$ では, パネルの判断特性関数のモデル として, 帯関数モデルが提案されており，この帯関数に基づ いてパネルの検査能力を分析する手法について以降考察す る。一般に，官能検査を行なううえでパネルに求められる検 査能力は, 判断基準の安定性, 鋭敏さなどである ${ }^{1)}$. そこで 本論文では，パネルの検査能力を示す新たな二つの評価指 数，すなわち，判断基準のばらつきの評価指数および分解能 の評価指数を帯関数から求める手法を提案し，これらの評価 指数を用いることで，簡便かつ数量的にパネルの検査能力 が分析できることを明らかにする．また，これら二つの評価 指数を用いて実問題のデータの分析に適用し，「彩度判定実 験」では，実験時にパネルに行なう説明の仕方の相違による パネルの検査能力の違いから，実験により適した説明はいず れかを容易に選ぶことができることを明らかにする。また， 「真珠らしさの判定実験」では，評価指数によってパネルの 検査能力を分析し，実験に適した実験条件やパネルの属性を 明らかにし，適正なパネルの選別が可能であることを示す.

\section{2. 帯関数モデルの概要 ${ }^{2), 3)}$}

\section{1 帯関数の定義}

まず，各試料 $X_{i}(i=1,2, \cdots, n)$ があるとき，それぞれ が持つ尺度值を $m_{i}(i=1,2, \cdots, n)$ とし， $X_{i}$ の $X_{j}$ に対す る比較判断結果を $\varphi_{i j}$ とする。これにより， $X_{i}, X_{j}$ の刺激 差 $\mu_{i j}=m_{i}-m_{j}$ に対する $\varphi_{i j}$ より，パネルの判断特性関 数を得ることができる。このとき，外乱の影響などからパネ ルの判断は同一の刺激差に対して常に一定ではなく，ある程 度幅を持つ範囲に収まるばらつきを持つと考えられる。した がって，パネルの反応 $\varphi_{i j}$ と刺激差 $\mu_{i j}$ の関係は Fig. 1 に 示すような二つの関数 $f_{d}(x), f_{u}(x)$ を用いて,

$$
f_{d}\left(\mu_{i j}\right) \leq \varphi_{i j} \leq f_{u}\left(\mu_{i j}\right)
$$

と表わすことができる。この場合；刺激差が大きくなれば大 きくなるほどパネルの反応も大きくなると考えられるため， $f_{d}(x), f_{u}(x)$ は単調増加関数となる.この二つの単調増加関 数に囲まれた帯状の領域を帯関数と呼び，パネルの判断特性 はこの帯関数によって表わされる.

\section{2 帯関数の近似的導出}

帯関数を求めるということは, 二つの単調増加関数 $f_{u}(\mu), f_{d}(\mu)$ を決定することである.しかし，実際の検査で は刺激差 $\mu_{i j}$ は離散的なものとなるため, $f_{u}(\mu), f_{d}(\mu)$ を全 域的に求めることはできない，そこで，ままず，一対比較デー

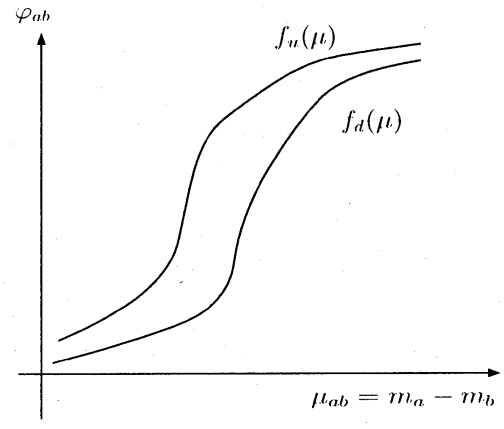

Fig. 1 Band function model

夕を処理して $m_{i}(i=1,2, \cdots, n)$ を求めることになる。あ る刺激差 $\mu_{i j}=m_{i}-m_{j}$ を持つ比較対を比較したときのパ ネルの反応 $\varphi_{i j}$ は，一対比較実験によって与えられるので， この結果に対応して Fig. 1 の $\mu-\varphi$ 平面上の一点を定める ことができる，同様にすべてのデータが定まると，それらす べての点 $\left(\mu_{i j}, \varphi_{i j}\right)$ は $(1)$ 式の関係と定義より, 帯関数の内 部点集合となる。

離散的な点集合から帯関数を推定する手法としては, 膨張操 作による手法 ${ }^{4)}$ などがあるが，ここでは簡単のため，すべて の点 $\left(\mu_{i j}, \varphi_{i j}\right)$ を挟み込み, かつ帯幅 $w(x)=f_{u}(x)-f_{d}(x)$ が最小となるように点と点を直線によって結んで得られる領 域から, 二つの単調増加関数 $f_{u}(\mu), f_{d}(\mu)$ を求めることに する。

\section{3. 評価指数の導入}

\section{1 判断のばらつきの評価指数 $I_{d}$}

一対比較実験において，パネルは同一の刺激差 (比較対) に対しては同一の反応を示すことが望ましいが，そのよう な場合には，そのパネルの持つ判断特性は幅をもたない一 本の単調増加関数で表わされる。しかしながら，一般的にパ ネルは同一の刺激差に対して安定な反応を示すわけでなく, 判断にばらつきが生じることが多い. パネルの判断にばらつ きが生じる場合，パネルの判断特性は，同一の刺激差に対し て幅を有する帯関数で表わされる．判断特性関数が幅を持つ とき，与えるべき尺度值の差の大小関係とパネルの判断結 果の大小関係との間に矛盾が生じる場合が現れる。ここで Fig. 2 に示す刺激差が $\mu, \mu^{\prime}$ である二つの一対比較判断の関 係について考える．このとき， $\mu^{\prime}<\mu$ であるとし， $\mu^{\prime}$ に対 するパネルの反応は $\varphi^{\prime}$ である. $f_{u}(\mu), f_{d}(\mu)$ は刺激差が $\mu$ となる二つの試料を比較対としたときのパネルの反応の最 大值，最小值を意味することを考慮すると， $\varphi^{\prime}<f_{d}(\mu)$ な らば,

$$
\begin{aligned}
\varphi>\varphi^{\prime} \\
\Leftrightarrow \mu>\mu^{\prime}
\end{aligned}
$$

が成り立つ.しかし，Fig. 2 に示すように， $\varphi^{\prime}>f_{d}(\mu)$ なら ば，必ずしも $\varphi>\varphi^{\prime}$ とはならず，本来与えるべき刺激差の 


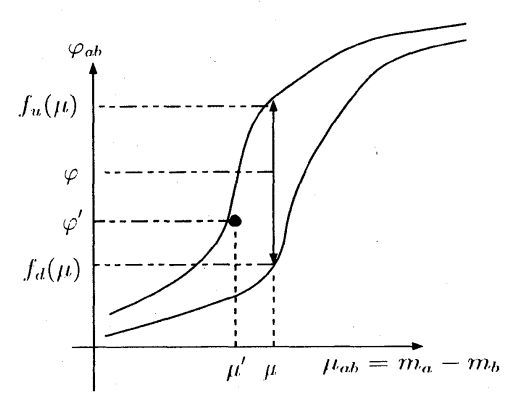

Fig. 2 Contradiction case on $\mu$ and $\varphi$

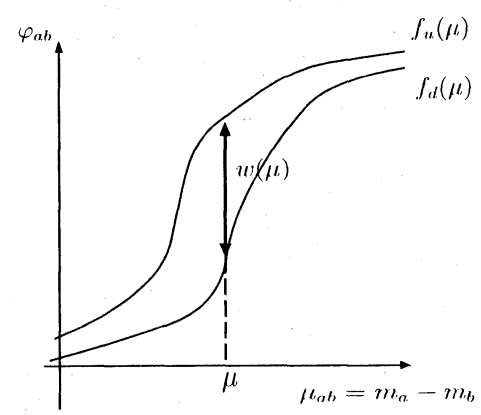

Fig. 3 Band width : $\omega(\mu)$

関係 $\mu>\mu^{\prime}$ とパネルの反応の大小関係が矛盾した， $\varphi<\varphi^{\prime}$ となることがある。この傾向は带幅が広がるほど大きくなる ため, 帯幅が極端に広い判断特性関数を持つパ六ル，すなわ ち判断にばらつきが多いパネルの回答には矛盾が多く含ま れることになる。したがって,ばらつきの程度はパネルの検 查能力を示す重要な指標である.

そこで，帯関数の帯幅からパネルの判断のばらつきについ て評価する。帯関数は Fig. 3 のように二つの単調増加関数 $f_{u}(x), f_{d}(x)$ に囲まれた領域として表わされるため，ある刺 激差 $\mu=m_{i}-m_{j}$ に対する帯幅 $\omega(\mu)$ は

$$
\omega(\mu)=f_{u}(\mu)-f_{d}(\mu)
$$

で与えられる。一般に，带幅は刺激差によって異なるため, 帯関数全体についての平均帯幅を, パネルの「判断のばら つき」の評価指数として考える. 刺激差の最大值を $\mu_{\max }$, 最小值を $\mu_{m i n}$ とすると「判断のばらつき」の評価指数 $I_{d}$ は,

$$
I_{d}=\frac{1}{\mu_{\max }-\mu_{\min }} \int_{\mu_{\min }}^{\mu_{\max }} \omega(x) d x
$$

によって表わされる。評価指数 $I_{d}$ はパネルの判断のばらつ きの程度を示しているため， $I_{d}$ が小さいパネルほど検查能 力は高いといえる.

\section{2 分解能の評価指数 $I_{r}$}

一対比較法では，二つの試料を比べたときの違いを判断し ているが，2つの刺激を区別する上で必要な最小の刺激差が 分解能であるといえるので，これを弁別䦨の大きさで表わす こととする．分解能の小さいパネルからは，分解能が大きい パネルでは区別できないような微妙な試料間の刺激差に対
しても充分に信頼できる回答を得ることができ，小さい分解 能を持つパネルは優れた比較判断能力を持つといえる.

パネルが違いを正しく区別できる最小の刺激差をそのパ ネルの持つ分解能と考え, 試料間の刺激差とパネルの反応の 関係について以下考察する。まず, 試料 $X_{i}$ と $X_{j}$ を比較し たときの反応を考える。一般的に，パネルの反応は，試料間 の刺激差が十分に大きいとき，すなわち，

$$
\left|m_{i}-m_{j}\right| \gg 0
$$

ならば，パネルは二つの試料の違いをまちがいなく区別で きる. 一方, 試料間の刺激差が小さくなるほどパネルの反応 は小さく曖昧なものとなる．最終的に二つの試料間の刺激 差が,

$$
\mu_{t}>\left|m_{i}-m_{j}\right|
$$

となったときパネルは二つの試料を正しく区別することがで きなくなり，二つの試料加の刺激を同程度と判断すること になる。このような知覚可能な最小の刺激差は弁別閾と呼ば れるが，この弁別闇の大きさをパネルの持つ分解能の指数と する.

つまり，一対比較においては，どちらの試料の刺激が大き いかを正確に判断できるということは，二つの試料の違い が正しく弁別されていると考えることができる。すなわち， ある刺激差 $\mu_{i j}=m_{i}-m_{j}$ に対するパネルの判断

$$
f_{d}\left(\mu_{i j}\right)<\varphi\left(\mu_{i j}\right)<f_{u}\left(\mu_{i j}\right)
$$

において，パネルが二つの試料の刺激が全く同じであると感 じたときの判断を， $\varphi_{\text {mid }}$ とすると，

$$
f_{d}\left(\mu_{i j}\right)>\varphi_{\text {mid }}
$$

または，

$$
f_{u}\left(\mu_{i j}\right)<\varphi_{\text {mid }}
$$

ならば，パネルは $m_{i}, m_{j}$ のどちらの刺激が大きいかを明確 に区別しているといえる. 順序効果がない場合, 带関数は $\left(0, \varphi_{\text {mid }}\right)$ に対して点対称になるはずであるから, Fig. 4 に 示されるような, $f_{d}\left(\mu_{t}\right)=\varphi_{\text {mid }}$ なる $\mu_{t}$ を用いて

$$
I_{r}=\mu_{t}
$$

$$
\text { ただし, } f_{d}\left(\mu_{t}\right)=\varphi_{\text {mid }}
$$

とし， $I_{r}$ をパネルの「分解能」に関する評価指数と定義す る. 評価指数 $I_{r}$ は，パネルが区別できる最小の刺激差を示 しているため， $I_{r}$ が小さいパネルほど検査能力は高い.

\section{4. シミュレーションによる評価指数の有効性の確認}

本章では, 評価指数の有用性を確認するために行なったシ ミュレーションについて述べる.

4.1 シミュレーション方法

シミュレーションを行なうためには，任意の検査能力を持 つパネルに相当するデー夕を人工的に作成する必要がある. すなわち，各パネルが比較判断を行なったことに対応する一 


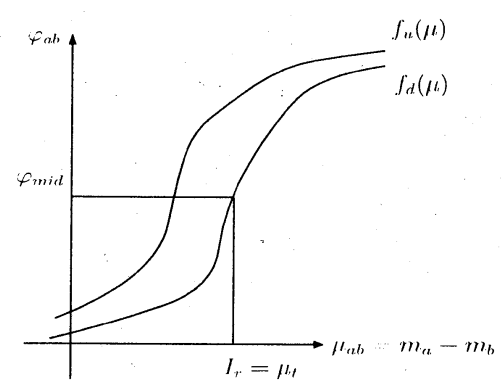

Fig. 4 Evaluation index of resolution : $I_{r}$

対比較表を人工的に作成し，この表につき各パネルの検査能 力を提案した評価指数を用いて評価する。 さらに得られた評 価指数値とパネルに想定した検査能力とを比較し, 正確にパ ネルの能力が評価できているかどうかを検証する.

具体的には，まず，ある刺激差 $\mu_{i j}=m_{i}-m_{j}$ に対する パネル $P_{n}$ の反応 $\varphi_{i j}$ を以下の手順によって決定する.

パネル $P_{n}$ のもつ判断のばらつきを $d_{n}$, 分解能を $r_{n}$ と 想定したとき，まず，パネルの中心的判断特性関数 $f_{n}(x)$ を, 単調増加性を考慮して,

$$
\begin{aligned}
f_{n}(x)=s|x|^{t} \cdot \operatorname{sgn}(x) & \\
s, t & >0,
\end{aligned}
$$

とする。ただ, 分解能の定義より $|x|>r_{n}$ ならば,

$$
\operatorname{sgn}\left(\mu_{i j}\right)=\operatorname{sgn}\left(\varphi_{i j}-\varphi_{m i d}\right)
$$

を満たさなくてはならないので， $\mu_{i j}>r_{n}$ のとき，

$$
f_{n}\left(\mu_{i j}\right)+\frac{d_{n}}{2}>\varphi_{m i d}
$$

となるように $(\mathrm{s}, \mathrm{t})$ の値を決定する.

このような $f_{n}\left(\mu_{i j}\right)$ を利用し, 刺激差 $\mu_{i j}$ を受けたとき のパネル $P_{n}$ の反応 $\varphi_{i j}$ を,

$$
\varphi_{i j}=R\left(f_{n}\left(\mu_{i j}\right),\left(d_{n} / 2\right)^{2}\right)
$$

によって決定する。ただし， $R\left(a, \sigma^{2}\right)$ は，平均が $a$ ，分散 $\sigma^{2}$ を持つ正規分布に従う正規乱数である。

以上の操作をすべての $i, j$ の組み合わせについて行ない, 一対比較表を作成する.

つぎにこのようにして作成した一対比較表から带関数を 導出し評価指数を求めることによって，パネル $P_{n}$ の検査能 力を評価する。

\section{2 判断のばらつきに関するシミュレーション結果}

前節の方法に従い, 判断のばらつき $d_{n}$ を一定にし, 分解 能 $r_{n}$ をランダムに定めたパネル 1000 名分のデータを作成 して, 判断のばらつきの評価指数值 $I_{d}$ を計算し, その平均 を求めた結果を Fig. 5 に示す．横軸が設定した判断のばら つき $d_{n}$, 縦軸がシミュレーションによって得られた評価指 数值 $I_{d}$ の平均值である.このグラフから，設定した判断の ばらつきとシミュレーションによって得られた評価指数值は ほぼ一致していることがわかる。

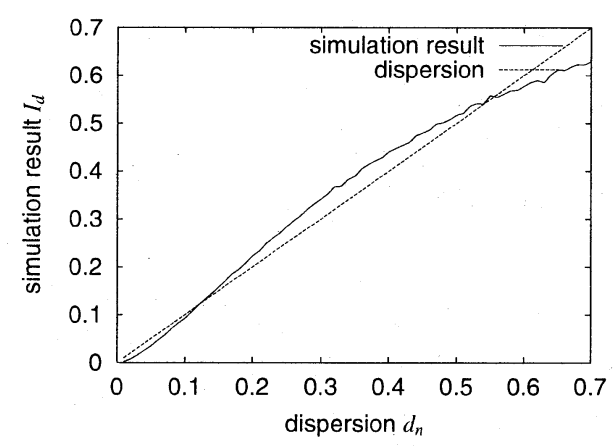

Fig. 5 Simulation result : Dispersion $I_{d}$

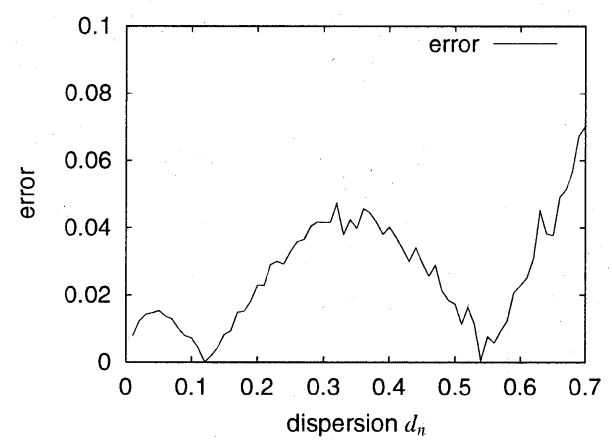

Fig. 6 Error of simulation result : Dispersion $I_{d}$

一方，Fig. 6 にシミュレーション結果と実際に設定した 值との誤差を示す。これから，判断のばらつきが 0.5 以下で あれば誤差は 0.05 以下であり，検査能力をほほ正しく評価 できていることがわかる。

\section{3 分解能に関するシミュレーション結果}

他方, 分解能 $r_{n}$ を一定にし，判断のばらつき $d_{n}$ をラン ダムに定めたパネル 1000 名分のデータを作成し，分解能の 評価指数值 $I_{r}$ の平均を求めた結果を, Fig. 7 に示す。また, 実際の分解能とシミュレーションによって得られた評価指数 值との誤差を示したものが Fig. 8 である.

Fig. 7 より，実際の分解能に比べ評価指数值は大きくなる 傾向があるが，Fig. 8 よりその誤差は 0.08 以下に抑えられ ており，評価可能といえる範囲に納まっている。

\section{4 シミュレーションからの結論}

以上のシミュレーションに示したように，判断のばらつ きおよび分解能の評価指数值の想定值との誤差が小さいこ とから, 判断のばらつき評価指数 $I_{d}$, 分解能の評価指数 $I_{r}$ 共に，パネルの検査能力の評価に活用できることが確認さ れた。

\section{5. 彩度判定実験：パネルに提示する情報の評価}

3 章で提案した評価指数を, 彩度判定の実験結果に適用し た. 本章では実験時にパネルに提示する情報が，比較判断の ばらつきに及ぼす影響について考察する。

\section{1 実験内容}

官能検査を行なう上で，パネルに何が問題にしたい刺激な 


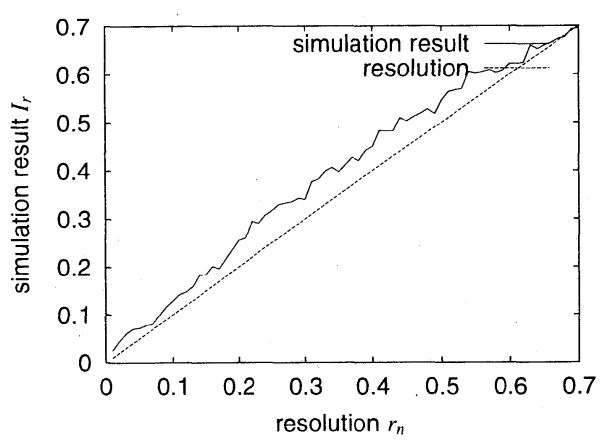

Fig. 7 Simulation result : Resolution $I_{r}$

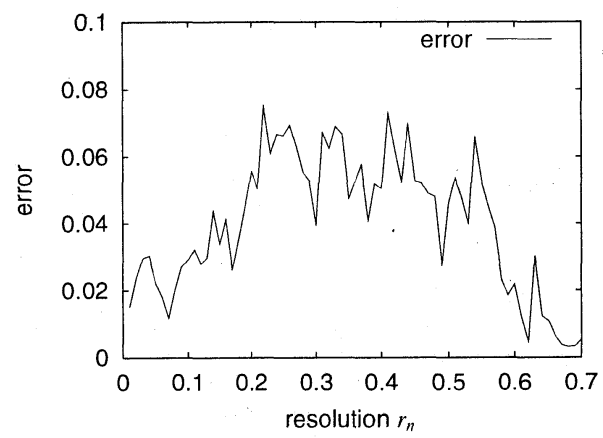

Fig. 8 Error of simulation result : Resolution $I_{r}$

のかを正確に伝えることは重要な作業である，問題にしたい 刺激に関する説明が不十分であると，パネルは実験者の意図 と異なった観点から回答を行なう可能性がある。一方, 問題 にしたいことを正確に伝えることができれば，パネルが比較 判断する際の曖昧さは減少し，より正確な判断が行なえるよ うになる。しかし，どのように説明すれば問題にしたいこと をパネルに正確に伝えることができるかの判断は難しい.

そこで, 本実験では, パネルに与える情報の内容を変える ことに伴う検査能力の変化を，提案した評価指数によって評 価する。この場合，検査能力が向上した場合には，実験者の 与えた情報によってパネルは問題とする刺激内容をより正し く理解したと考える.

\section{2 実験方法}

本実験では, 彩度值の異なる色見本の対を提示し, その鮮 やかさをパネルに比較させる一対比較実験を行なった。

このとき，パネルを 1 グループ 10 人前後のグループ四つ に分け，それぞれのグループに彩度に関する説明を異なる方 法で行ない，検査能力の違いを評価指数によって評価した. それぞれのグループに行なった説明の仕方は以下のとおりで ある。

・グループ 1: 説明は行なわない

・グループ 2: 言葉のみによる説明

・グループ 3: 色彩表のみによる説明

・グループ 4: 色彩表と言葉による説明

試料の色見本は全 9 種類で，それぞれ異なる彩度值の色見 本を用意した．色の鮮やかさは， $\mathrm{PC}$ 上で任意の数值を持つ
Table 1 Used colors' chroma saturation

\begin{tabular}{|c|c|}
\hline No. & Chroma saturation \\
\hline 0 & 1.00 \\
\hline 1 & 0.90 \\
\hline 2 & 0.80 \\
\hline 3 & 0.70 \\
\hline 4 & 0.60 \\
\hline 5 & 0.50 \\
\hline 6 & 0.40 \\
\hline 7 & 0.30 \\
\hline 8 & 0.10 \\
\hline
\end{tabular}

色を作成することが可能で，用いた色の彩度值を Table 1 に示す。なお，この数值は $\mathrm{PC}$ 上で作成できる最も大きい彩 度の色 0 の彩度を 1 として，規格化したものである.

実験は，液晶プロジェクタによってスクリーンに比較対を 同時に表示し, 二色の色についてどちらが鮮やかに見えるか をパネルに判定してもらった。

\section{3 実験結果と分析}

それぞれのグループごとに実験を行ない，再構成された 帯関数を Fig. 9〜Fig. 12 に示す. 縦軸にパネルの判断を， 横軸に Table 1 に示した彩度の值の差をとっている。また， Table 2 には各グループの評価指数值を示す.

Table 2 より，鮮やかさについて説明を受けなかったグ ループ 1 の評価指数值 $I_{d}, I_{r}$ はともに最も大きく，すなわ ち検査能力が最も低いということがわかる．つまり，パネル は実験前には鮮やかさについての正しい知識を正確には持っ ていなかったことが推察される。したがって，全く説明を行 なわずに実験を行なった場合，得られた結果の信頼性は非常 に低いものとなる。

つぎに，言葉によって鮮やかさの説明を行なったグループ 2 と色彩表を用いて鮮やかさの説明を行なったグループ 3 を 比較する．Table 2 より，色彩表を見るよりも，言葉によっ て説明を受けたほうが検査能力は高いことがわかる。また， 言葉によって鮮やかさを説明した場合の帯関数 (Fig. 10) は, 早い段階でパネルの判断が飽和しているのに対し，色彩表 のみによって説明した場合についての帯関数 (Fig. 11) では, 彩度が大きく異なる試料同士，すなわち $\mu_{i j}$ の絶対值が大 きい領域においても帯関数は飽和していない，以上のことか ら，鮮やかさの理解してもらうには，具体例を示すよりも， 概念的な説明のほうが効果は高いといえる。

一方，色彩表と言葉の両方によって鮮やかさの説明を行 なったグループ 4 は，グループ 2 よりもさらに高い検査能 力を示している.これは，言葉によって鮮やかさの概念を理 解し, さらに色彩表により具体的な彩度の違いを確認するこ とによって，より理解が深まったためであると解釈できる. ここで，鮮やかさに付いて全く説明を行なわなかったグ ループ 1 と，色彩表と言葉によって説明を行なったグルー プ 4 について比較してみる．まず，ばらつきの評価指数值 $I_{d}$ はグループ 4 についてはグループ 1 の半分以下なってい 
Table 2 Evaluation index value : each groups

\begin{tabular}{|c|c|c|}
\hline Group No. & $I_{d}$ & $I_{r}$ \\
\hline 1 & 0.469 & 0.600 \\
\hline 2 & 0.315 & 0.267 \\
\hline 3 & 0.384 & 0.300 \\
\hline 4 & 0.218 & 0.179 \\
\hline
\end{tabular}

ることがわかる。これは，すなわち説明を受けることによっ て判断に生じるばらつきが半分以下になったことを示して いる，一方，分解能の評価指数值 $I_{r}$ を比較すると，説明を 行なわない場合が 0.600 であるのに対し，説明を行なった 場合は 0.179 と大幅に減少している。すなわち，グループ 1 は彩度の差が 0.600 なければ,つまり, Table 1 の試料 0 と試料 6 を比較してはじめて正確にどちらの彩度が高いか を判断できるようになるのに対し，グループ 4 は彩度の差 が 0.18 程度,つまり試料 0 と試料 2 を比較しても正確に判 断できている。

また，Fig.13，Fig.14に，それぞれグループ 1，グルー

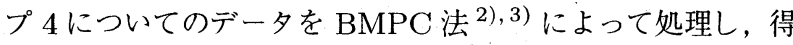
られた尺度值の結果を示す．説明を受けていないグループ 1 では実際の彩度の大きさの順と尺度づけされた結果が逆転 している場合が多く見られるが，色彩表と言葉によって説明 したグループ 4 では，逆転はほとんどなく，正確に鮮やかさ を評価できているといえる。

以上の結果から，鮮やかさを比較する実験を行なう際に は，言葉によって鮮やかさの概念を説明するとともに，色彩 表により彩度の違いの具体例を提示することによって, 検査 能力の飛躍的な向上が望めると解釈でき，このような事情が 提案した評価指数 $I_{d}, I_{r}$ で分析可能となった.

\section{6. 真珠らしさの判定実験：パネル選別への適用}

つぎに，提案した評価指数を用いて，長田らにより公表 されている真珠らしさの判定実験のデータについて分析を 行なった ${ }^{5)}$.この実験においては，未知の心理的尺度である 「真珠らしさ」について尺度づけするため一対比較実験が行 なわれている。この場合，パネルは「真珠らしさ」に対する 明確な概念を持っていることが前提となるが，この点，本章 では，この実験に参加したパネルの検査能力の分析を行な い，優れた検査能力を持つパネル，すなわち「真珠らしさ」 について明確な概念を持ったパネルの選別を行なうことを試 みる。

\section{1. 評価指数值の決定手順}

文献 5)によれば，真珠の拡大写真から，それぞれ異なっ た部分の 7 つの写真が切り出されたものが用意され，そこ から二つを採り出しては「どちらがより真珠らしいか」を比 較判断させている。この場合，比較のため実物の真珠を見せ ながら評価してもらう場合と見せずに評価してもらう場合 の二通りの実験を行なっている．また，真珠を見せた場合， 見せなかった場合のそれぞれについて男女別パネルのデー

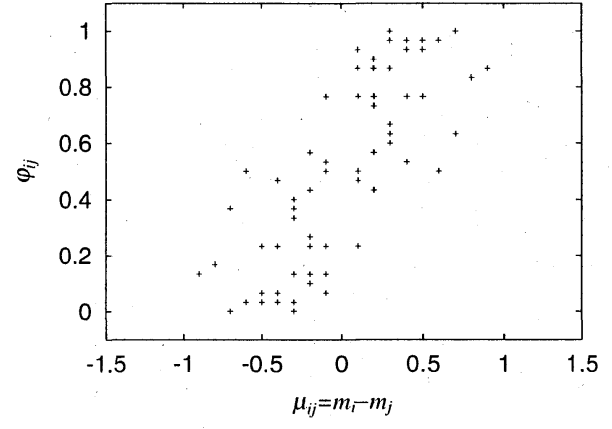

Fig. 9 Band function about group 1

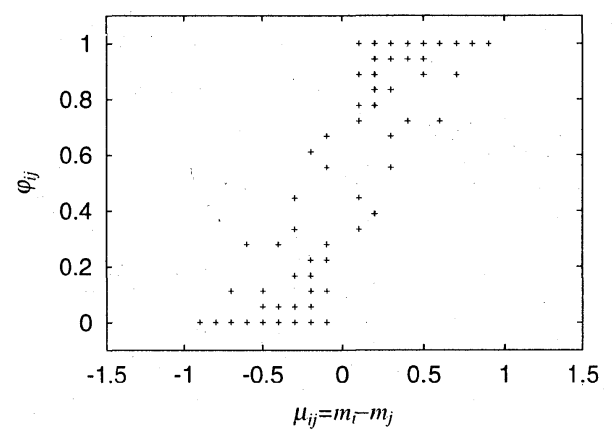

Fig. 10 Band function about group 2

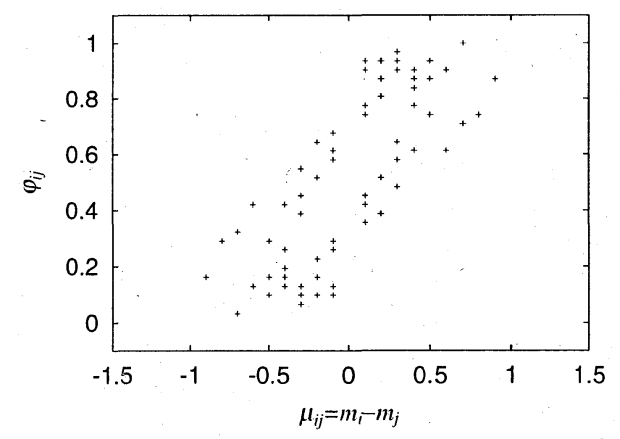

Fig. 11 Band function about group 3

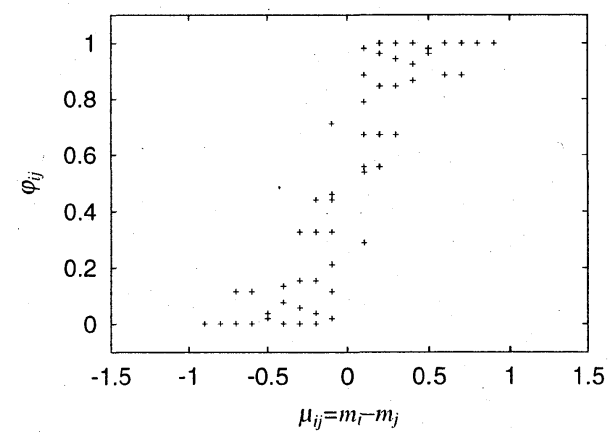

Fig. 12 Band function about group 4

夕もある。そこで，これら一連の一対比較デー夕について BMPC 法を適用し，それぞれの真珠の部分写真に「真珠ら しさ」の尺度值を与え，さらに得られた尺度值を真の尺度值 と見なして帯関数を構成した。 


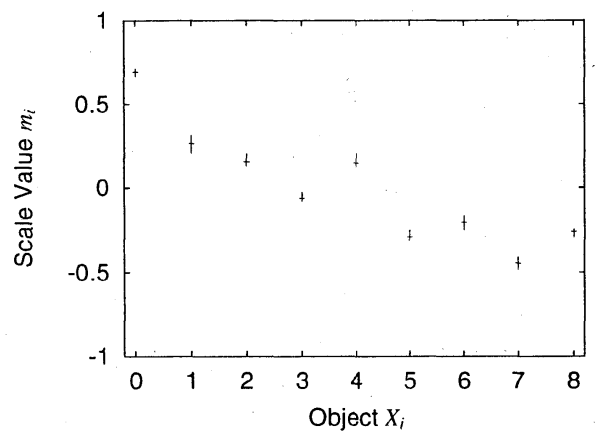

Fig. 13 Determined scale value: Group 1

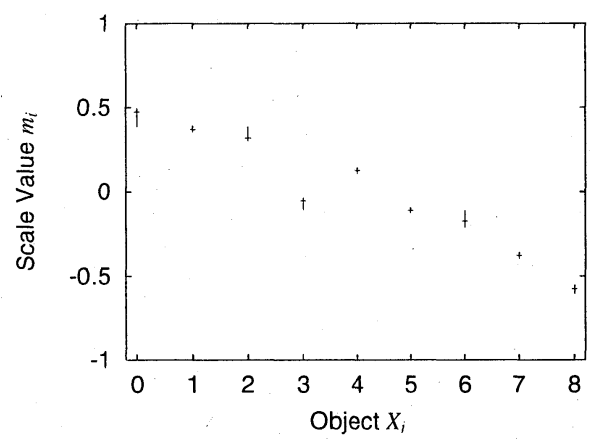

Fig. 14 Determined scale value : Group 4

Table 3 Evaluation index value : all groups

\begin{tabular}{|c|c|c|}
\hline Pearl indication & $I_{d}$ & $I_{r}$ \\
\hline With indication & 0.134 & 0.043 \\
\hline Without indication & 0.191 & 0.174 \\
\hline All & 0.188 & 0.036 \\
\hline
\end{tabular}

それら帯関数に基づいて求められた評価指数值が Table 3

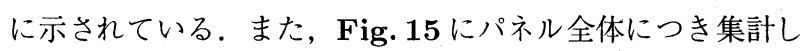
た一対比較デー夕に関する帯関数を示す。なお，各パネルの 回答から求めた各真珠の心理的尺度值 $m_{i}(i=1,2, \cdots, N)$ は,

$$
\begin{aligned}
& \sum^{N} m_{i}=0 \\
& \sum^{N} m_{i}^{2}=1
\end{aligned}
$$

となるように規格化してある。

\section{2 検査能力の分析と考察}

まず，本物の真珠を見せた場合，パネルは本物の真珠を見 ることで「真珠らしさ」について予備知識を持つことにな る.この結果, 部分写真を見て「真珠らしさ」を判断すると きに「本物の真珠」を基準にすることができるため，どちら がより真珠らしいかの判断が容易になることが考えられる. この点, Table 3 よれば, 確かに本物の真珠を見せたパネル の評価指数は, 判断のばらつき, 分解能, ともに本物の真珠 を見せていない場合に比べ小さくなっている．すなわち，本 物の真珠を見せたパネルが行なった「真珠らしさ」の比較に おいて, 回答のばらつきは小さく安定しており, また, 真珠

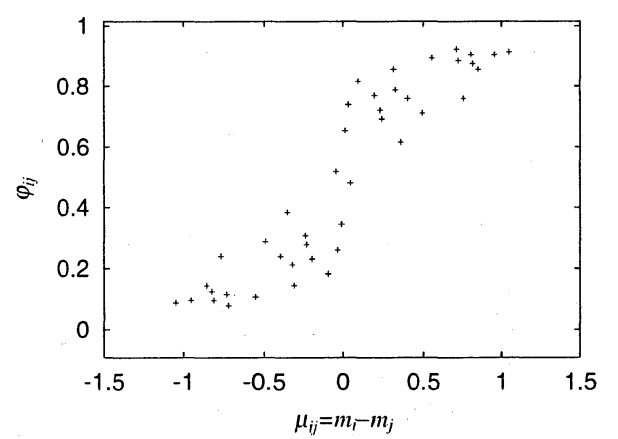

Fig. 15 Band function about all panel

Table 4 Evaluation index value : detailed analysis

\begin{tabular}{|l|c|c|c|}
\hline Pearl indication & & $I_{d}$ & $I_{r}$ \\
\hline \multirow{2}{*}{ With } & female & 0.151 & 0.069 \\
\cline { 2 - 4 } & male & 0.163 & 0.154 \\
\hline \multirow{2}{*}{ Without } & female & 0.150 & 0.038 \\
\cline { 2 - 4 } & male & 0.242 & 0.201 \\
\hline
\end{tabular}

らしさにあまり差がない場合でも，どちらがより真珠らしい かを的確に判断できているといえる.

つぎにさらに詳しく実験条件による検査能力の違いを見る ため，男女それぞれに関し実物の真珠を見せた場合と，実物 の真珠を見せていない場合の評価指数值を Table 4 に示す.

この Table 4 より, 男性のパネルは, 実物の真珠を見せる ことによって「ばらつき」の評価指数值が 0.242 から 0.163 となり, 判断のばらつきが小さくなっている.「分解能」の評 価指数值も 0.201 から 0.154 となり，真珠を見せた場合は， 尺度づけれた「真珠らしさ」の差が小さくても明確に区別 して回答していることがわかる。一方，女性のパネルは，実 物の真珠を見た場合でも見ていない場合でも，検査能力はほ とんど変化していない.

以上のことは，男性は実物の真珠を見ることによって「真 珠らしさ」の概念が明確になり検査能力が向上するが，女性 はもともと「真珠らしさ」の概念が明確であるため, 実物の 真珠を見せても，ほとんど検査能力に変化が起こらないと考 えられる。

\section{3.パネルの選別について}

以上の結果から,「真珠らしさ」の尺度づけを行なうにつ いて,

（1）男性のパネルには実物の真珠を見せながら比較し てもらったほうがよい

（2）女性のパネルには実物の真珠を見せなくてもその 回答には信頼性がある

といえよう。この二点を考慮し，実物の真珠を見ながら比較 を行なった男性パネルの回答，および，すべての女性パネル の回答を集計した一対比較表を作り，このデータにつき同様 な分析を行なった. Fig. 16 が，選別されたパネルによる結 果から得られた帯関数である.Fig. 15 の帯関数と比べ，帯 幅が小さく，パネルの回答についてのばらつきが減っている 


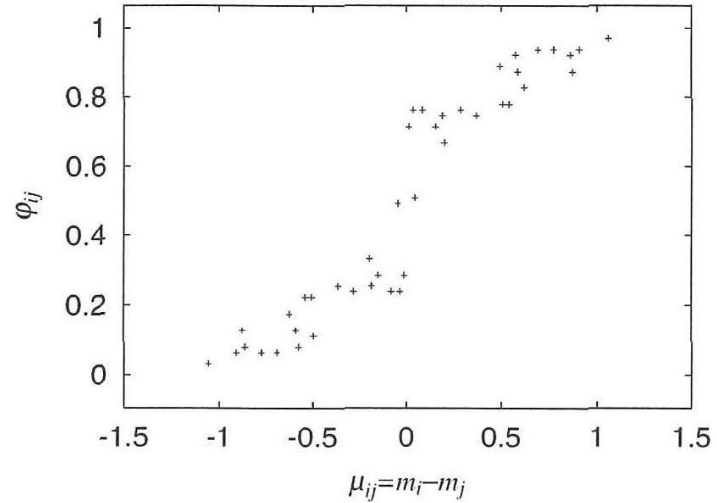

Fig. 16 Band function about selected panel

ことがわかる。これは、「真珠らしさ」に対し明確な概念を 持たないパネルを排除したことによって，全体の回答につい てのあいまいさの程度が減少したためであると考えられる。

\section{7. 結論}

本研究ではパネルの判断の質が異なれば判断特性を表わ す帯関数が異なるものになることに注目し，それぞれのパネ ルの検査能力を評価する方法について検討した.

すなわち，帯関数の帯幅の広さからパネルの持つ判断のば らつきを評価する指数を，また，パネルが試料からの刺激の 程度の違いを正しく弁別できる刺激差からパネルの持つ分 解能を評価する指数を提案した。

つぎにこれら二つの評価指数の有用性を検証するため， 人工的につくった一対比較表を用いてシミュレーションを行 ない,これらの評価指数によってパネルの検査能力を評価す ることが可能であることを明らかにした。

さらに, 提案した二つの評価指数を「彩度判定実験」に適 用し，パネルに与える情報の効果について評価し，その結 果，求めるべき刺激をパネルに正確に伝えることのできる説 明方法の判定が可能となることを示した。

またここれら二つの評価指数を「真珠らしさの判定実験」 にも適用し，パネルの属性および，実験条件による検査能力 の違いの分析を行なった，その結果，検査に適したパネルと 実験条件を明らかにし，信頼性のあるパネルを分類できるこ とを確認した.

なお，最後に「真珠らしさ」の実験の詳細なデータを提供 していただきました三菱電気（株）の長田典子氏，大阪大学 大学院井口征士教授に感謝致します.

$$
\text { 参 考 文 献 }
$$

1）日科技連官能検查委員会:官能検查ハンドブック，日科技連出版 社 (1973)

2）小林, 坂本:帯関数モデル型一対比較法のための数值処理法とそ の解領域. 計測自動制御学会論文集，18-4,377/384(1982)

3）鳥海, 曹, 大川l, 小林:BMPC 法における解領域と解頌域更新新 アルゴリズム。計測自動制御学会論文集，37-9,886/892(2001)

4) 小林, 坂本:順序効果がある一対比較結果の処理. 計測自動制御 学会論文集, 21-8,771/777(1982)
5) 長田, 宇佐見, 真鍋, 井口:品質評価のためのビジュアルシミュ レーションによる真珠の表現. 電子情報通信学会論文誌, D-11 Vol.J80-D-11-1, 206/214(1997)

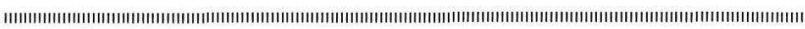

$$
\text { [著 者 紹 介] }
$$

鳥 海 不二夫（学生会員）

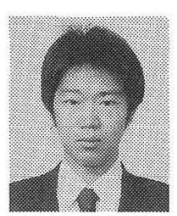

2001 年, 東京工業大学大学院理工学研究科制 御工学専攻修士課程修了, 同年同大学院理工学研 究科機械制御システム専攻博士課程入学, 現在に 至る.

\section{高 山 潤 也（正会員）}

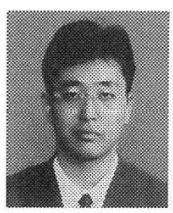

1998 年, 東京工業大学大学院修士課程修了. 同 年日産自動車 (株) 入社. 2000 年, 東京工業大学 大学院理工学研究科機械制御システム専攻助手, 現在に至る．高度能動計測系としての信号場の理 論とその応用などの研究に従事.

\section{大 山 真 司（正会員）}

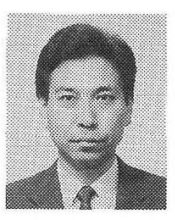

1984 年, 東京工業大学大学院修士課程修了. 同 年 (株) 日立製作所日立研究所入社.90 年, 東京 工業大学工学部助手, 現在, 同学大学院理工学研 究科助教授、計測工学, 計測システム構成論等の 研究，教育に従事. 86 年度本学会論文賞受賞. IE $\mathrm{EE}$, 電子情報通信学会の会員 (博士 (工学)).
小 林

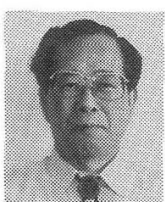

\section{涁（正会員）}

1969 年, 東京工業大学大学院博上課程修了。同 年東京工業大学助手. 87 年同教授, 現在に至る。 計測用空間フィルタ，感覚計測，解領域法によ る信号処理, 信号場, 高 SN 比計測法などの研究 に従事. $73,80,86$ 年度本学会論文賞受賞.96 年フェロー (工学博士).

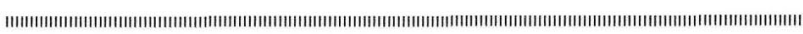

